\title{
The role of the Golgi apparatus in disease (Review)
}

\author{
JIANYANG LIU, YAN HUANG, TING LI, ZHENG JIANG, LIUWANG ZENG and ZHIPING HU \\ Department of Neurology, Second Xiangya Hospital, Central South University, Changsha, Hunan 410011, P.R. China
}

Received August 12, 2020; Accepted January 15, 2021

DOI: $10.3892 /$ ijmm.2021.4871

\begin{abstract}
The Golgi apparatus is known to underpin many important cellular homeostatic functions, including trafficking, sorting and modifications of proteins or lipids. These functions are dysregulated in neurodegenerative diseases, cancer, infectious diseases and cardiovascular diseases, and the number of disease-related genes associated with Golgi apparatus is on the increase. Recently, many studies have suggested that the mutations in the genes encoding Golgi resident proteins can trigger the occurrence of diseases. By summarizing the pathogenesis of these genetic diseases, it was found that most of these diseases have defects in membrane trafficking. Such defects typically result in mislocalization of proteins, impaired glycosylation of proteins, and the accumulation of undegraded proteins. In the present review, we aim to understand the patterns of mutations in the genes encoding Golgi resident proteins and decipher the interplay between Golgi resident proteins and membrane trafficking pathway in cells. Furthermore, the detection of Golgi resident protein in human serum samples has the potential to be used as a diagnostic tool for diseases, and its central role in membrane trafficking pathways provides possible targets for disease therapy. Thus, we also introduced the clinical value of Golgi apparatus in the present review.
\end{abstract}

\section{Contents}

1. Introduction

2. Golgi apparatus structure and function

3. Structural and functional changes of the Golgi apparatus in diseases

4. Mutant Golgi resident proteins involved in disease

5. Golgi apparatus membrane trafficking disorders

6. Clinical value of Golgi apparatus

7. Conclusion

Correspondence to: Professor Zhiping $\mathrm{Hu}$, Department of Neurology, Second Xiangya Hospital, Central South University, 139 Renming Road, Changsha, Hunan 410011, P.R. China

E-mail: zhipinghu@csu.edu.cn

Key words: Golgi apparatus, Golgi dysfunction, Golgi resident protein, disease, diagnosis, therapy

\section{Introduction}

The Golgi apparatus is a processing and sorting hub in the transport and targeting of soluble cargo proteins and lipids to different destinations in the cell (1). Considering its central role in the secretory pathway, alterations in the structure and function of the Golgi apparatus are expected to affect the homeostasis of cellular proteins and lipids. Increasing evidence suggests that structural changes and functional disorder of the Golgi apparatus are involved in many human diseases such as neurodegenerative diseases (2-4), ischemic stroke $(5,6)$, cardiovascular diseases $(7,8)$, pulmonary arterial hypertension $(9,10)$, infectious diseases (11-13), and cancer (14). However, much work is still needed to elucidate how the Golgi apparatus affects the progression of these diseases.

In this review, we describe the central roles of the Golgi apparatus in cells, and discuss diseases associated with structural changes and functional disorder of the Golgi apparatus. We highlight some of the studies that explore links between mutation in genes encoding Golgi resident proteins and human diseases. By analyzing their pathophysiology, we found that the majority of genes leading to human diseases are involved in membrane trafficking. Considering the mechanistic links between Golgi resident proteins, membrane trafficking, and the development of genetic diseases, we suggest a term for these disorders based on their similar pathophysiology: Golgi apparatus membrane trafficking disorders.

\section{Golgi apparatus structure and function}

In 1898, the Italian anatomist Camillio Golgi initially described the cell organelle that bears his name, the Golgi apparatus (15). The Golgi apparatus is characterized by a series of flattened, cisternal membrane structures forming the so-called Golgi stack, which is surrounded by vesicles. Based on the distribution of resident proteins, the Golgi stack can be divided into three regions: The cis-, medial-, and trans-Golgi cisternae (16). The Golgi stacks in vertebrate cells are laterally interconnected by tubular membranes and exhibit a twisted ribbon-like network known as the Golgi ribbon (17). The structure of the Golgi ribbon is supported by the Golgi matrix (18). The Golgi matrix is believed to comprise highly dynamic structural proteins, which is important for structural integrity and vesicular trafficking.

The Golgi apparatus has two main functions. The first is the post-translational protein modification. Similar to glycosylation, it is a common post-translational modification 
occurring in the endoplasmic reticulum (ER) and Golgi and the glycan processing occurs throughout the Golgi stacks. The second is the sorting, packing, routing and recycling of these modified cargos to the appropriate cellular destinations (1). The main secretory pathway can be divided into the following steps (19): First, newly synthesized proteins or lipids enter the exit sites of the ER and are sorted into budding vesicles that are dependent on the COPII. Second, vesicles move to the ER-Golgi intermediate compartment (ERGIC) and forward to the cis-Golgi networks (CGN). Third, proteins or lipids enter cis-Golgi cisternae and move towards the trans-Golgi cisternae. Vesicular transport and cisternal maturation are the two classical models of intra-Golgi transport (20). The vesicular transport model proposes that Golgi cisternae are static, and the cargos are transported through them by COPI vesicles. The cisternal maturation model suggests that cisternae are dynamic structures, while Golgi enzymes are recycled via retrograde transport of COPI vesicles. Fourth, vesicles reach the trans-Golgi networks (TGN), which are involved in the sorting of products to their final destinations such as lysosomes, endosomes, or the plasma membrane.

\section{Structural and functional changes of the Golgi apparatus in diseases}

The structural integrity of the Golgi apparatus is vital for its normal function, and Golgi fragmentation could result in a wide range of diseases and disorders. Functional changes of the Golgi Apparatus include perturbations in Golgi $\mathrm{pH}$, aberrant Golgi glycosylation, and membrane trafficking. Golgi fragmentation has been found to often be an early causative event in the process of cell apoptosis $(21,22)$. With pharmacological or oxidative stress, a series of changes occur in the Golgi apparatus, such as cargo overloading, ionic imbalance, and abnormal luminal acidity. These changes can lead to defects in membrane trafficking. We previously presented 'Golgi stress' as a new concept to explain the Golgi-specific stress response (23). The Golgi stress response constitutes autoregulation to repair the Golgi apparatus and may initiate signaling pathways to alleviate stress. The nucleus signaling pathways of the Golgi stress response was identified in a previous study: The procaspase-2/golgin-160, TFE3, HSP47, and the CREB3-ARF4 pathways (24). If these pathways fail to repair overstimulation, the Golgi is completely disassembled, inducing cell apoptosis.

Apoptosis triggered by structural changes and functional disorder of the Golgi contributes to the pathogenesis of many diseases, such as neurodegenerative diseases (25), ischemic stroke $(5,6)$, cardiovascular diseases (26), pulmonary arterial hypertension $(9,10)$, infectious diseases $(12,13)$, and cancer (27). A summary of diseases relating to the Golgi apparatus, classified on the basis of the main organ affected is shown in Fig. 1.

Neurodegenerative disease. Structural and functional changes of the Golgi apparatus are associated with several neurodegenerative diseases, such as Amyotrophic lateral sclerosis (28), Alzheimer's disease (29), Parkinson's disease (3), Huntington's disease (30), Creutzfeldt-Jacob disease (31) and multiple system atrophy (32). Golgi fragmentation is not a consequence of apoptosis, but a very early event in the pathological cascade in neurodegenerative disorders and precedes other pathological changes in the neuron (33). Golgi fragmentation may alter neuronal physiology, and induce failures in transport to axons, dendrites, and synapses (34). Finally, Golgi alteration may trigger a stress response and, as consequence, result in neuronal death. Furthermore, Golgi fragmentation in neurodegenerative disease alters protein trafficking and production, such as amyloid precursor protein in Alzheimer's disease (35), and sodium-dependent vitamin $\mathrm{C}$ transporter 2 in Huntington's disease (36). The causes of Golgi fragmentation in neurodegenerative diseases may be diverse. First, alteration of the microtubule and microfilament stabilization may also be the cause (37). In Alzheimer's disease and other tauopathies, tau-induced microtubule-bundling may result in Golgi fragmentation (38). Furthermore, perturbations in Golgi $\mathrm{pH}$ are also responsible for Golgi fragmentation. The Purkinje cells from the Golgi $\mathrm{pH}$ regulator conditional knockout mice exhibited Golgi fragmentation, followed by axonal degeneration and neuronal loss (39).

Infectious disease. Golgi fragmentation has been identified in diseases such as infection by Orf virus (12), Chlamydia trachomatis (40,41), Hepatitis C virus (HCV) (42), Human Rhinovirus (HRV) (13), and Rickettsia rickettsii (43). Golgi fragmentation in these infectious diseases is mainly reflected in two aspects: i) Escaping from the immune response. In infected cells, Golgi fragmentation reduces MHC class I complex surface expression by defective membrane trafficking $(43,44)$, which may aid in escaping host cellular immune recognition (12); ii) Enhancing viral replication. In human rhinovirus-1A infection, the Golgi in host cells is fragmented and rearranged into vesicles that appear to be used as the membrane source for the assembly of viruses (45). Similarly, in Oropouche virus replication, proteins in the endosomal sorting complex required for transport in the host cell are hijacked in Golgi cisternae to mediate remodeling of Golgi membranes, resulting in enlargement of the Golgi stacks, where the endosomal sorting complex required for transport participates in the assembly of viral factories (46). Thus, structural changes in the Golgi apparatus may enhance viral replication in infectious diseases by providing membranes.

Cancer. Aberrant Golgi glycosylation is reported to regulate invasion of cancer cells, such as in prostate (47), breast (48), and gastric cancer (49). Golgi glycosylation is involved in basic molecular and cellular biology processes occurring in cancer, such as cell signaling transduction and communication, cancer cell dissociation and invasion, cell-matrix adhesion, cancer angiogenesis, immune regulation and metastasis (50). Similar to epithelial cadherin, a transmembrane glycoprotein, is involved in epithelial cell-cell adhesion in tumors (51). The Golgi glycosylation of N-linked glycans on epithelial cadherin can affect the epithelial-mesenchymal transition, which is related to the formation of metastatic lesions (49). This process is suggested to help cancer cells leave their original position during wound healing and other normal physiological processes, which is an essential mechanism for metastasis and diffusion of cancer cells $(52,53)$. The GOLPH3 complex is an important molecular component in the process of Golgi-driven 


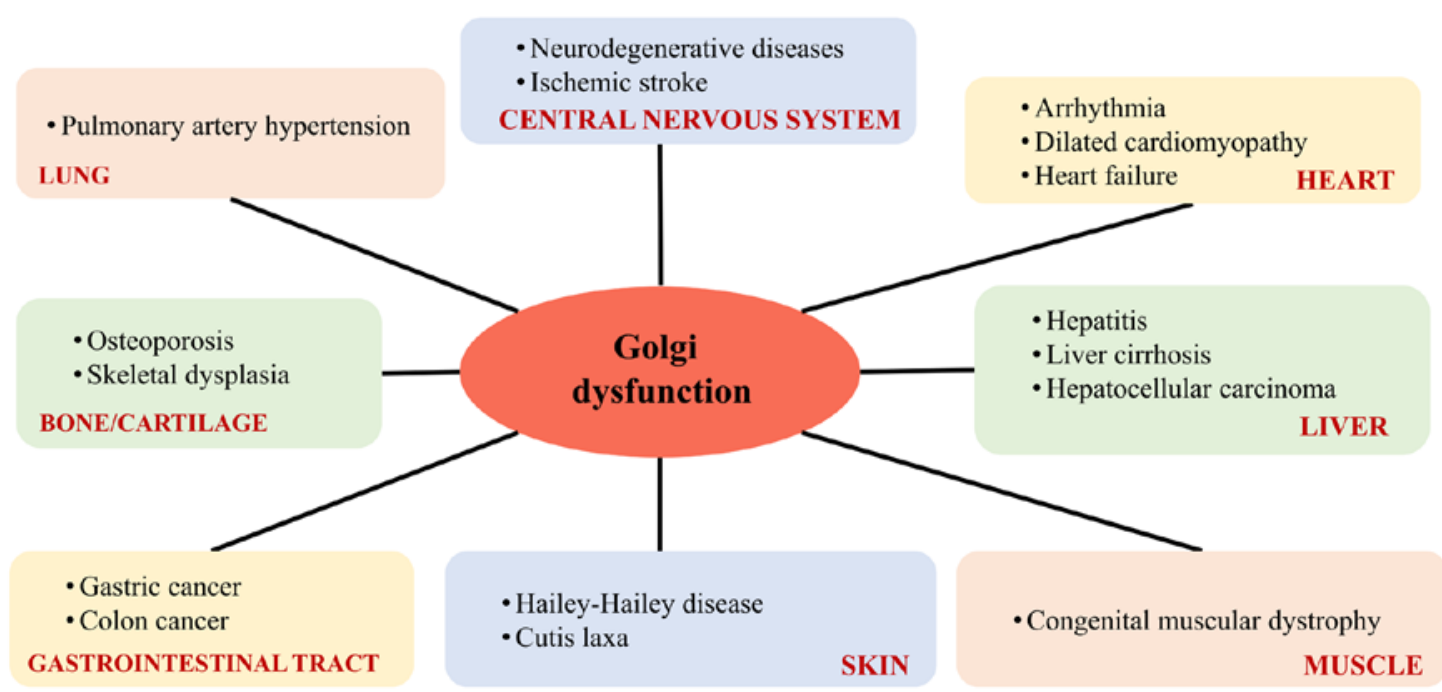

Figure 1. Disorders relating to Golgi dysfunction. Disorders relating to Golgi apparatus dysfunction are grouped according to the main tissues/organs affected.

tumor progression. The role of the GOLPH3 complex in cancer includes: i) Regulating Golgi glycosylation, which is important in driving the cancer phenotype (54); ii) promoting the cellular DNA damage response that enhances cellular survival under DNA damage (55); iii) interacting with components of the retromer complex that enhances growth-factor-induced mTOR signaling (56); and iv) regulating cell migration by promoting reorientation of the Golgi apparatus towards the leading edge (57). In addition to GOLPH3, the Golgi protein GM130 is important in Golgi glycosylation and protein membrane trafficking in cancer cells. Downregulation of GM130 induces autophagy, inhibits glycosylation, decreases angiogenesis, and suppresses tumorigenesis (58). In general, aberrant Golgi glycosylation causes carcinogenesis, but may also be a consequence of cancer progression.

Other diseases. Golgi dysfunction was also observed in pulmonary arterial hypertension, and cardiovascular diseases. In an in vivo model of pulmonary arterial hypertension, Golgi dysfunction and intracellular trafficking with trapping of diverse vesicle tethers, giantin, p115, and soluble $\mathrm{N}$-ethylmaleimide-sensitive factor attachment protein receptors (SNAREs) were observed in the Golgi membranes of enlarged pulmonary arterial endothelial cells and smooth muscle cells $(9,10,59)$. Golgi-mediated membrane trafficking dysfunctions play important roles in the pathogenesis of pulmonary arterial hypertension (60).

Structural changes and functional disorder of the Golgi apparatus have been identified in many cardiovascular diseases, such as heart failure, dilated cardiomyopathy, arrhythmia, and chronic arial fibrillation (61-64). A previous review clarified the relationship between the Golgi apparatus and various cardiovascular diseases (26). For example, in dilated cardiomyopathy patients, morphological changes in Golgi vesicle are consistent with the secretion of natriuretic peptide as the rate of protein secretion affects the morphology and size of Golgi vesicles (7). In addition, the Golgi vesicle area is inversely proportional to the left ventricular end-diastolic diameter and the end-systolic diameter, and is proportional to the left ventricular ejection fraction (65).

\section{Mutant Golgi resident proteins involved in disease}

In addition to being an intermediate site in pathogenic cascades in diseases, the Golgi apparatus can be the primary target for diseases caused by genetic mutations in Golgi resident proteins. Mutations in proteins localized to the Golgi apparatus can be deleterious for the structure and function of this organelle, impeding membrane trafficking pathways through it (Fig. 2) and resulting in disease. We highlight some of the studies that explore links between Golgi resident proteins and disease.

Golgi matrix protein and diseases. Adjacent Golgi stacks are linked by tubules forming a membrane network termed the Golgi ribbon (66). This structure is a highly ordered and continuous structure that is adjacent to the nucleus. The Golgi ribbon comprises proteins that mediate cisternal stacking and the material supporting the Golgi ribbon is the Golgi matrix (67). The concept of the Golgi matrix was introduced by Slusarewicz and colleagues, who isolated a detergent-insoluble, salt-resistant Golgi fraction in 1994 (18). The main function of the Golgi matrix is maintaining normal structure and mediating protein trafficking through the Golgi cisternae. During cisternal progression, the Golgi matrix must be dynamic to adapt to Golgi structural changes.

Golgi matrix proteins include golgins and Golgi reassembly stacking proteins (GRASPs) (67), both of which are important for maintaining Golgi structure and regulating protein and lipid trafficking through the stacks. Golgins are a family of conserved coiled-coil proteins that were originally identified as a group of Golgi-localized antigens $(68,69)$. The golgins not only capture incoming vesicles, but also clearly distinguish vesicles from different origins (70). GRASPs include GRASP65 (71) and GRASP55 (72). The former localizes to the cis-Golgi cisternae while the latter localizes to the medial/trans-Golgi cisternae. The functions of GRASPs include Golgi structure formation, specific cargo transport, apoptosis, and cell migration (73).

Given the important multiple functions of Golgi matrix proteins, mutation of Golgi matrix proteins has serious consequences on health. Increasing studies support that 


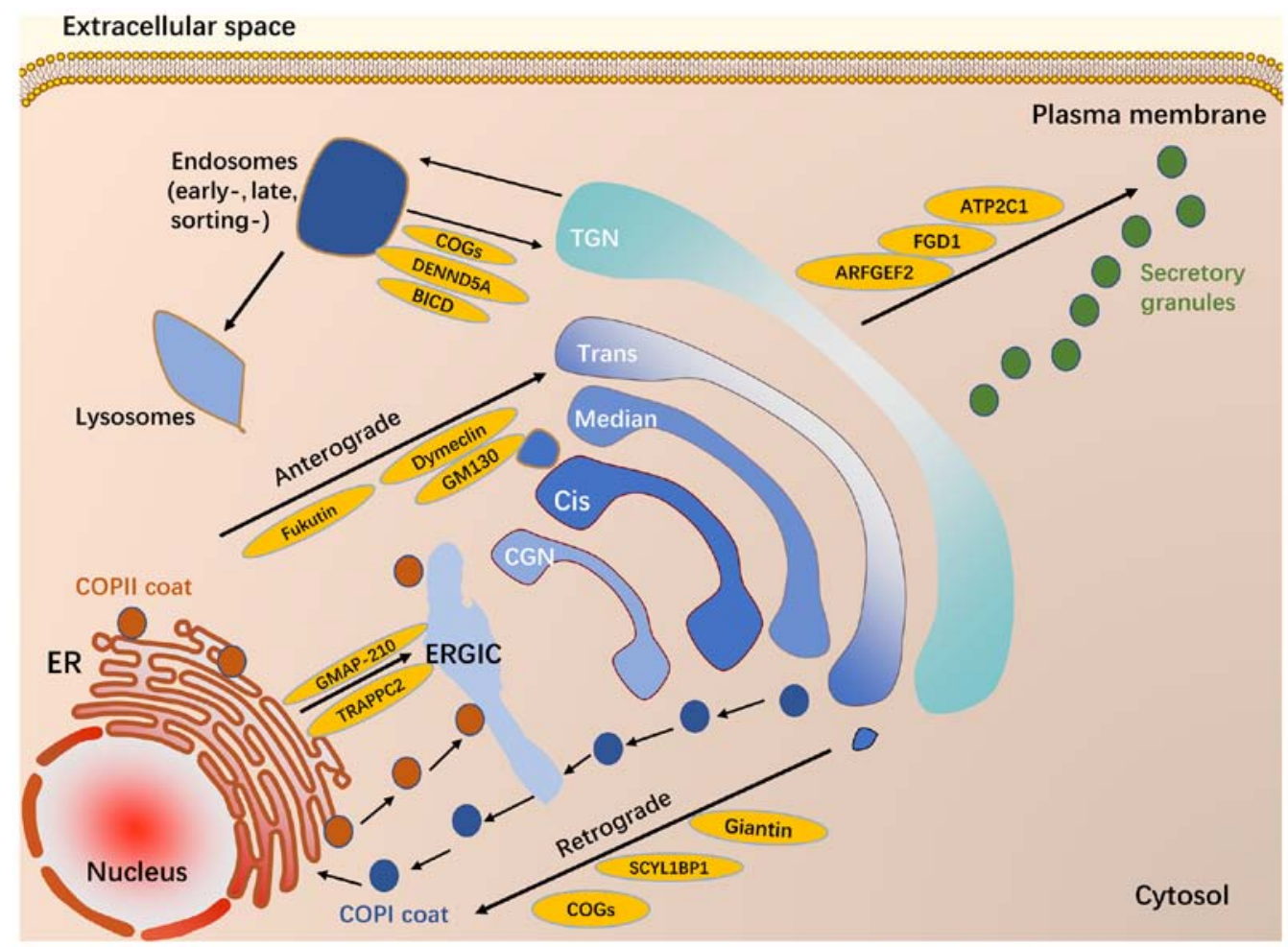

Figure 2. Golgi resident proteins and membrane trafficking pathway. The main membrane trafficking pathways are included. Newly synthesized proteins enter the ER and are sorted into budding vesicles that are dependent on the COPII. Vesicles move to the ERGIC and forward to the CGN and the trans-Golgi cisternae. Finally, vesicles reach the TGN and cargos sort to their final destinations such as lysosomes, endosomes or the plasma membrane. Different mutation in Golgi resident proteins affect different membrane trafficking pathway: i) GM130, Giantin, Fukutin, Dymeclin and SCYL1BP1 (involving anterograde trafficking); ii) COGs (involving retrograde trafficking); iii) TRAPPC2 and GMAP-210 (involving ER to ERGIC); iv) FGD1, ATP2C1 and ARFGEF2 (involving TGN to plasma membrane); and v) COGs, DENND5A and BICD (involving endosome to TGN).

the mutation of Golgi matrix proteins including GM130, Bicaudal-D (BICD), GMAP-210, giantin (74), and SCYL1BP1 (also known as GORAB) (75), leads to diseases. The present review included some proteins as examples to elaborate on the pathogenic mechanism of Golgi matrix proteins.

The first example is GM130 (also known as GOLGA2), the first identified Golgi matrix protein (76). GM130 is a peripheral membrane protein attached to the Golgi membrane that is important in maintaining the adaxial Golgi reticular structure (77). In neurodegenerative diseases, GM130 knockout in hippocampal neurons is reported to cause damage to dendritic structures (78). In mouse neuron experiments, specific knockout of GM130 resulted in disruption of the Golgi architecture and positioning in cerebellar Purkinje cells and to deficient secretory cargo trafficking. As a consequence, progressive cerebellar atrophy of Purkinje cells resulted in delayed movement and ataxia in mice (79). This animal experimental study indicates that GM130 mutations are causative in neurodegenerative disease.

A second example is BICD, a golgin that interacts with Rab6 on the TGN (80). Of two homologous sequences, BICD1 and BICD2, the latter binds to a subgroup of motility protein activator proteins and is a connecting molecule between the motility protein and cargo (81). High expression of BICD in normal nervous systems is important for maintaining the normal lamellar structure of the cerebral cortex, hippocampus, and cerebellar cortex (82). The brain cortex, hippocampus and cerebellar cortex neurons of BICD2-knockout mice have impaired migration function $(82,83)$ and eventually, damage the brain and cerebellar cortex layer structure. Previous findings showed that, missense mutations in $B I C D$ resulted in spinal muscular atrophy $(84,85)$ and hereditary spastic paraplegia (86) by changing the normal morphological structure of the golgi. The core pathogenetic mechanism may be a $B I C D 2$ mutation resulting in abnormal cargo trafficking in motor neurons. This trafficking results in neuronal growth disorders and eventually neuronal dysfunction.

The third example is giantin, encoded by the Golgbl gene. Giantin is a member of the golgin family and is a tethering factor for COPI vesicles and functions in the CGN (87). Mutations in the Golgbl gene lead to lack of expression of giantin protein and a pleiotropic phenotype including osteochondrodysplasia in a rat model (88) and a ciliopathy-like phenotype in a zebrafish model (74). Both pathogenetic mechanisms involve disturbance of extracellular matrix components, which are transported by intracellular membrane trafficking systems. Giantin knockout leads to changes in expression of Golgi-resident glycosyltransferases, which could affect extracellular matrix deposition (89).

The fourth example is GORAB (also known as SCYL1BP1). GORAB, localized to the trans-side of the Golgi, is a member of the golgin family and interacts with Rab6. Mutation in GORAB results in gerodermia osteodysplastica (GO) characterized by wrinkly skin and osteoporosis (75). GORAB functions in COPI trafficking, and acts as a scaffolding factor for COPI assembly at the TGN by interacting with Scyll. GORAB mutations perturb COPI assembly at the TGN, and result in reduced recycling of COPI-mediated retrieval of trans-Golgi enzymes and improper glycosylation (90). 
A final example of the effects of loss of expression of a Golgi matrix protein is GMAP-210 (also known as TRIP11). This CGN golgin acts in asymmetric membrane tethering (91). In animal experiments, a nonsense mutation in Trip11 led to a loss of GMAP-210, which led to abnormal Golgi-mediated glycosylation and cellular transport of proteins in chondrocytes and osteoblasts of mice (92). Similarly, GMAP-210 mutations were found in patients with human chondrodysplasia achondrogenesis 1A (92), and odontochondrodysplasia (93).

Other Golgi resident proteins and diseases. In addition to matrix proteins, several proteins that localize to Golgi membranes are also important for normal Golgi structure and function such as the tethering factors Rab GTPases and SNAREs, which regulate the specific targeting and fusion of transport carriers with Golgi membranes. The maintenance of Golgi luminal ion concentrations depends on the secretory pathway $\mathrm{Ca}^{2+} / \mathrm{Mn}^{2+}$ ATPases and vacuolar $\mathrm{H}^{+}$ATPase (V-ATPase). Therefore, the impaired performance of mutated Golgi resident proteins creates serious and highly diverse pathologies in the Golgi. Emerging studies on patient genetics have identified mutations in Golgi resident protein-coding genes that are related to diseases. We focus on some of these proteins, and discuss the activities of mutated Golgi resident proteins that result in disease.

Golgi ion pump. The release and uptake of $\mathrm{Ca}^{2+}$ by Golgi membranes is mainly mediated by secretory pathway $\mathrm{Ca}^{2+} / \mathrm{Mn}^{2+}$ ATPases (SPCA1 and SPCA2), which are encoded by the ATP2C1/ATP2C2 genes. The proteins transfer $\mathrm{Ca}^{2+}$ from the cytoplasm to the Golgi and maintain the stability of intracellular free $\mathrm{Ca}^{2+}$ (94). The maintenance of Golgi luminal $\mathrm{Ca}^{2+}$ and $\mathrm{Mn}^{2+}$ directly affects the optimal activity of Golgi glycosyltransferase and the trafficking of cell adhesion proteins to the cell plasma membrane (95). Knockdown of SPCAl affects the morphology and structure of the Golgi and causes mis-localization of proteins. Clinically, mutations in the ATP2Cl gene on chromosome 3q21 can lead to Hailey-Hailey disease, an autosomal dominant skin disorder in humans $(96,97)$. The possible pathogenetic mechanism may be dysfunction in $\mathrm{Ca}^{2+}$ signaling at the Golgi membrane and dysfunction of processing, modification and trafficking of desmosomal proteins (98).

Golgi acidity is an important role for maintaining the morphological integrity of the Golgi and transporting various kinds of cargo $(99,100)$. Under normal conditions, the Golgi cavity is weakly acidic and the $\mathrm{pH}$ of the Golgi reticular structure decreases gradually from the CGN to the TGN (101). The Golgi luminal $\mathrm{pH}$ is regulated by V-ATPase (102), AE2a $\mathrm{HCO} 3 / \mathrm{Cl}^{-}$exchanger, and Golgi $\mathrm{pH}$ regulator (103). Luminal $\mathrm{pH}$ is closely tied to Golgi function. Partial V-ATPase dysfunction is related to multiple disease states (104). ATP6VIE1, ATP6V1A, and ATP6V0A2 encode different subunits of the V-ATPase pump. A study showed that Golgi subunit-isoform of the V-ATPase (ATP6V0A2) mutations lead to structural changes in the extracellular matrix that is responsible for skin elasticity (105). Clinically, the dysfunction of the Golgi-localized V-ATPase caused by mutations in the ATP6VOA2 gene is directly related to cutis laxa. Mutations in ATP6VIEl or ATP6VIA also cause autosomal-recessive cutis laxa (106). Autosomal recessive cutis laxa type II is a heterogeneous condition characterized by sagging, inelastic, and wrinkled skin $(107,108)$. The mechanism may involve impaired intracellular acidification of the Golgi and damaged retrograde trafficking from the Golgi to the ER $(100,108)$.

ATP7A and ATP7B are the key regulators of cellular $\mathrm{Cu}^{2+}$ metabolism. Under basal conditions (normal copper levels), ATP7A is located in the TGN and travels to the plasma membrane at high copper levels. Mutations in the ATP7A result in mislocalization of ATP7A protein and impaired copper-responsive trafficking between the TGN and plasma membrane, which contributes to the development of Menkes disease (109). Menkes disease is a lethal multisystemic disorder characterized by neurodegeneration and connective tissue abnormalities as well as typical sparse and steely hair. Similarly, mutations in the $A T P 7 B$ contributes to the development of Wilson's disease (110). Wilson's disease, also known as hepatolenticular degeneration, results in hepatic and/or neurological deficits, including dystonia and parkinsonism.

Golgi resident glycosyltransferase. The Golgi apparatus is an important organelle for the post-translational modification of cargos. The post-translational modification of secreted and membrane proteins is mediated by the Golgi resident enzymes such as glycosyltransferases, glycosidases, and kinases. Glycosylation is an enzymatic reaction that chemically links monosaccharides or polysaccharides (glycans) to other saccharides, proteins, or lipids (111). Golgi glycosylation is a modification by Golgi-resident glycosylation enzymes including glycosidases and glycosyltransferases (112). The normal function of Golgi glycosylation depends on the precise Golgi localization and normal activities of Golgi resident enzymes. The proper localization of Golgi resident enzymes is controlled by finely regulated vesicular trafficking in the Golgi. If the balance between anterograde and retrograde trafficking is defective, Golgi glycosylation is affected, resulting in Golgi glycosylation abnormalities (113). Mutations in Golgi resident putative glycosyltransferases are directly linked to human congenital muscular dystrophies: Like-acetylglucosaminyl-transferase (LARGE) in congenital muscular dystrophy syndrome (114), fukutin in Fukuyama-type congenital muscular dystrophy (115), and fukutin-related protein in band muscular dystrophy syndrome (116). These mutations appear to affect cell migration in the developing brain, resulting in combined clinical manifestations in muscle and brain development. In an animal model, mutations in Golgi resident glycosyltransferases are also associated with the neurodegenerative disease, such as ST3GAL5, $\beta 1,4$-gala ctosyltransferase 4 (B4GalT4) (117), and glycosyltransferase 8 domain containing 1 (GLT8D1). GLT8D1 is a glycosyltransferase enzyme located in the Golgi apparatus. A recent study reported that mutated GLT8D1 induces motor deficits in zebrafish embryos consistent with amyotrophic lateral sclerosis (118). However, another study suggested that GLT8D1 is not likely the causative gene for ALS in mainland China (119).

Rab GTPase. Rab proteins are members of the small Ras-like GTPase family that regulate the four steps of membrane transport by recruiting effector molecules. Golgi-associated Rab proteins including Rab1, Rab2, Rab6, Rab18, Rab33B, and 
Rab43 have a central role in Golgi organization and membrane trafficking (120). Rab33B is localized to medial-Golgi cisternae and is important in Golgi-to-ER retrograde trafficking. Rab39B, a neuronal-specific protein, is a novel Rab GTPase that localizes to the Golgi and is related to synapse formation. Mutations in the Rab33B coding gene cause Smith-McCort dysplasia (121) and mutations in the Rab39B gene cause X-linked mental retardation (122).

SNAREs. SNAREs are proteins involved in docking and fusion of transport to intermediate membranes. Golgi SNAP receptor complex member 2 (GOSR2) is a member of the SNAREs family that localizes to the CGN and is involved in ER-to-Golgi trafficking (123). Homozygous mutations in GOSR2 lead to progressive myoclonus epilepsy (124). Clinical manifestations include early ataxia, myoclonus, and convulsive seizures. A possible mechanism involves GOSR2 mutations leading to GOSR2 protein that cannot be localized to the CGN and blocks SNAREs complex formation. SNAREs complex dysfunction could lead to the impaired fusion of vesicles with cis-Golgi cisternae, hindering ER-to-Golgi membrane trafficking. The perturbation of early ER-to-Golgi transport may result in changes in the regulated release of neurotransmitters and proper sorting of neurotransmitter receptors at synapses in neurons, potentially leading to epilepsy $(125,126)$.

\section{Golgi apparatus membrane trafficking disorders}

In the above section, we introduced the pathophysiology of some diseases related to Golgi resident proteins. A summary of genetic diseases caused by mutations in genes encoding Golgi resident proteins is presented in Table I. By analyzing the pathophysiology of these diseases, we found that the majority of genes leading to human diseases are involved in defects in membrane trafficking (Fig. 2). For example, TRAPPC2 mutation, involving the membrane trafficking pathway between ER-to-Golgi in bone cells and chondrocytes, results in X-linked spondyloepiphyseal dysplasia tarda (127). The conserved oligomeric Golgi (COG) complex is a conserved, hetero-octameric protein complex localized in the Golgi cis/medial cisternae (128). In addition to the COG3 subunit, mutations in seven other COG subunits result in human congenital disorders of glycosylation (CDG) type II, which is mainly marked by misregulation of protein glycosylation, and defects in retrograde trafficking through the Golgi $(129,130)$. The mutation in FGDl resulting in Aarskog-Scott syndrome may lead to the obstruction of post-Golgi trafficking, such as the Golgi-to-plasma membrane trafficking pathway (131). Mutation in TRIPI1 mainly involves ER to ERGIC and anterograde trafficking (132). Therefore, membrane trafficking defects play a major role in the pathogenic process of mutation in genes encoding Golgi resident protein. Intracellular membrane trafficking is a fundamental process responsible for compartmentalization of the biosynthesis pathway and secretion cargos, including hormones, growth factors, antibodies, matrix and serum proteins, digestive enzymes, and many more. Defective membrane trafficking results in protein sorting defects, undegraded proteins due to defective Golgi-to-lysosome trafficking, downregulation of protein secretion, and mislocalization of proteins.
Considering the mechanistic links between Golgi resident proteins, membrane trafficking, and the development of genetic diseases, we suggest a term for these disorders based on their similar pathophysiology: Golgi apparatus membrane trafficking disorders. It is a group of genetic diseases in which the mutation of the gene encoding Golgi resident protein results in membrane trafficking defects within the cells. Golgi apparatus membrane trafficking defects typically result in the accumulation of undegraded proteins, mislocalization of proteins, and impaired glycosylation of proteins. However, the cascade events following the Golgi apparatus and defective membrane trafficking, ultimately leading to human diseases, remain to be clarified in further research.

Although the Golgi apparatus-mediated membrane trafficking pathway exists in all kinds of tissues and organs in human, the trafficking defects on tissues is often selective. The most sensitive to membrane trafficking defects is the nervous system, skin, bone, cartilage, and skeletal muscle and the reasons for mutations occurring in these genes mostly affecting these tissues remain to be elucidated. Firstly, neurons are extraordinarily polarized cells, the extension of dendrites and axons requires a significant expansion of the cell surface area, and new plasma membrane proteins must be delivered through the membrane trafficking. For the nervous system, intracellular trafficking functionally impacts neuronal development, homeostasis, as well as neurodegeneration (133). Secondly, it is generally known that skin, bone, cartilage, and skeletal muscle fiber comprise large amounts of the extracellular matrix which define the structure and physical properties. Almost all extracellular matrix components are transported by intracellular trafficking systems. Alterations in Golgi apparatus membrane trafficking can lead to glycosylation abnormalities. The assembly and maintenance of the extracellular matrix are susceptible to impairment of matrix protein glycosylation. Thus, the skin, bone, cartilage, and skeletal muscle are most sensitive to impaired glycosylation of cargo proteins, and membrane trafficking defects. Therefore, the loss of some Golgi resident proteins, such as ATP6V1A, ATP6V1E1 (106), ATP6VOA2 (108), TMEM165 (134), GOLGB1 (88), SCYL1BP1 (75), TRAPPC11 (135), TRAPPC2 (136), and TRIP11 (92), manifest primarily in these matrix-rich tissues.

\section{Clinical value of Golgi apparatus}

The Golgi apparatus participates in the occurrence and development of disease and could be the key to finding new targets for disease diagnosis and therapy.

Biomarker discovery. Golgi glycoprotein 73 (GP73, also referred to as GOLPH2), a resident Golgi membrane protein, is predominantly expressed in biliary epithelial cells in the normal human liver (137). GP73 expression is upregulated in chronic Hepatitis B virus (HBV) infection (138), chronic $\mathrm{HCV}$ infection (139), non-alcoholic fatty liver disease (140), and hepatocellular carcinoma (HCC) $(141,142)$. Serum GP73, a new marker for HCC, is reported to appear earlier than serum $\alpha$-fetoprotein. The combined detection of serum $\alpha$-fetoprotein and GP73 can improve sensitivity and specificity for HCC diagnosis $(143,144)$. However, several studies showed GP73 levels were not higher in HCC patients than in patients with 


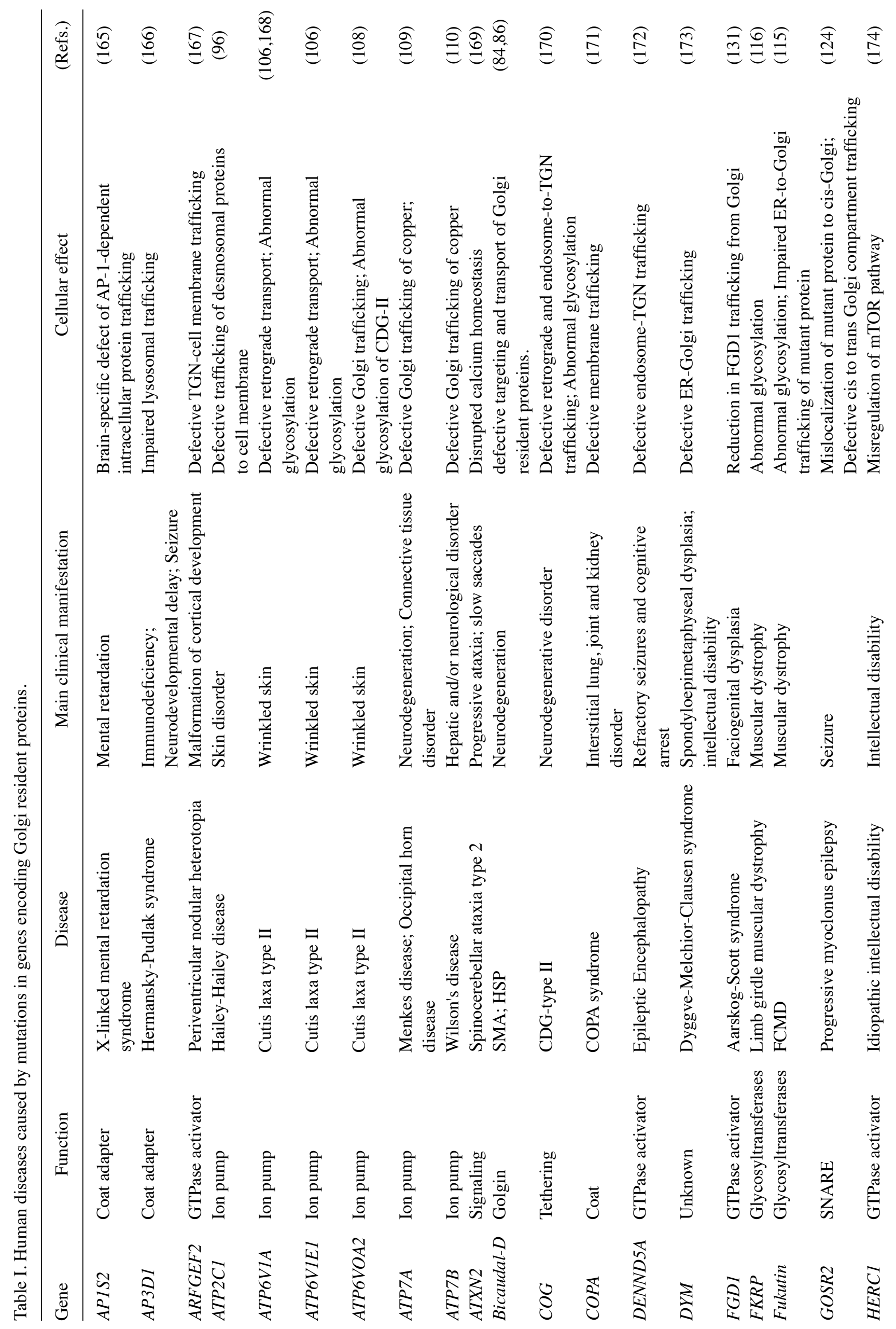




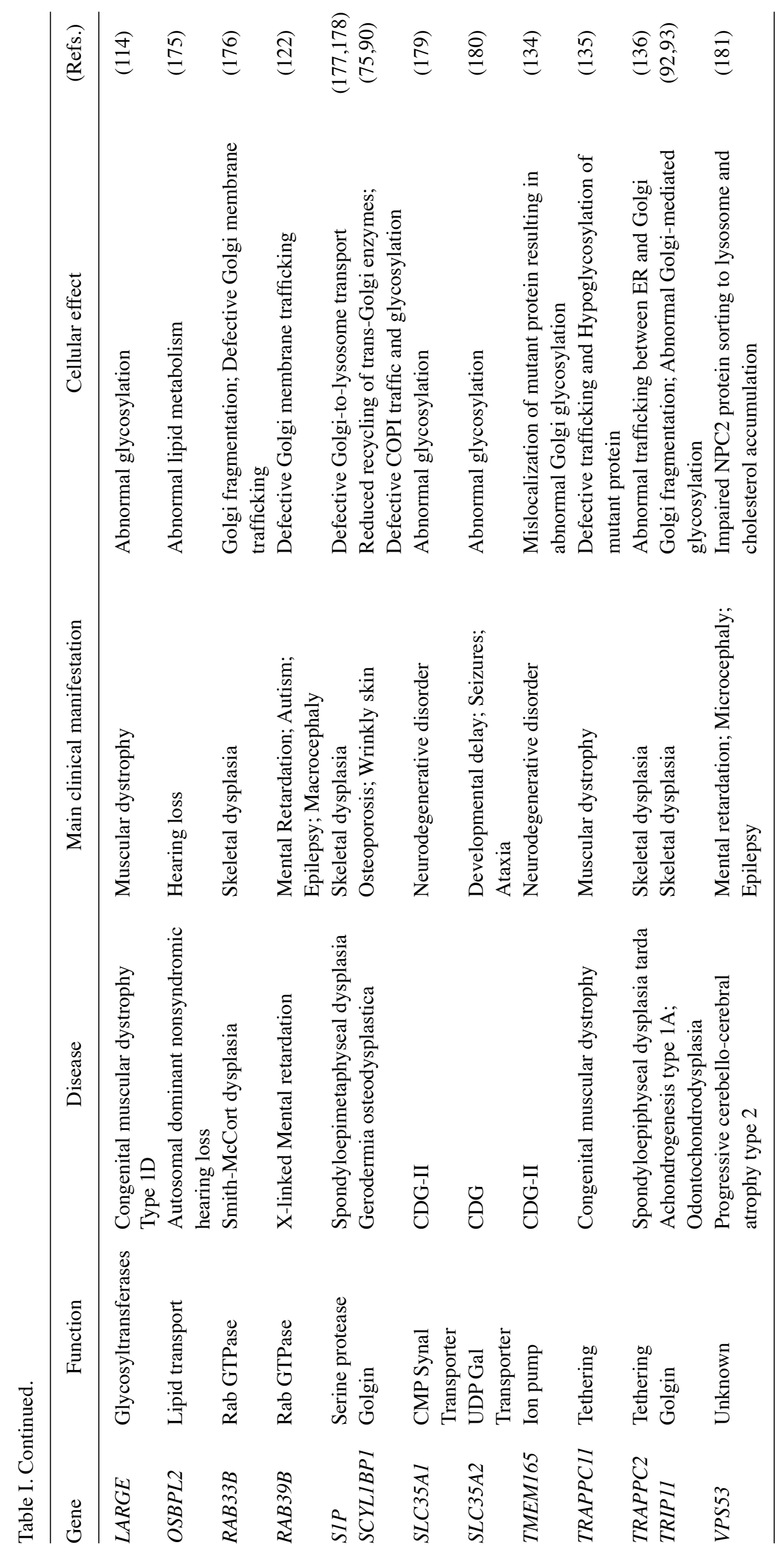


other liver diseases such as cirrhosis $(145,146)$. In addition to being a marker, the expression of GP73 is critical for chemotherapeutic resistance in HCC cell lines (147).

Transmembrane protein 165 (TMEM165) functions in ion homeostasis, membrane trafficking, and glycosylation in the Golgi apparatus (148). Findings of a study showed that mutations in TMEM165 cause CDG type II in humans (134). Other research has found that expression of TMEM165 mRNA and protein is apparently increased in HCC patient tissues and contributes to the invasive activity of cancer cells (149). This result indicates that TMEM165 is a possible biomarker for HCC. GS28 is a member of the SNAREs protein family. GS28 protein immunoreactivity was observed in both nuclear and cytoplasmic compartments of cancer cells. High nuclear expression of GS28 is associated with poor prognosis for colorectal (150) and cervical cancer patients (151).

Anti-Golgi antibodies (AGAs) were first found in 1982 in the serum of patients with Sjogren's syndrome complicated with lymphoma (152). AGAs have also been found in other immunological diseases (153-155). Currently, at least 20 Golgi autoantigens are known, including golgin-97, golgin-67, golgin-245, golgin-95, golgin-160, and giantin. AGA positivity is commonly found in connective tissue diseases such as Sjogren's syndrome, rheumatoid arthritis, and systemic lupus erythematosus $(154,156)$; cerebellar malignant disease such as idiopathic late-onset cerebellar ataxia (157); infectious diseases such as $\mathrm{HBV} / \mathrm{HCV}$ infection, Epstein-Barr virus infection and HIV infection $(155,158,159)$; and tumors, such as HCC and lung cancer (160). Although AGAs are not specific to any disease, their clinical detection may be helpful for classifying and following the progress of some connective tissue diseases. For example, compared to anti-BICD2-negative patients, single specificity anti-BICD2 patients may be more associated with inflammatory myopathy and interstitial lung disease (161).

Biomarkers are crucial for early diagnosis, assessing response to treatment, and classifying diseases into subtypes. Biomarker discovery involves many critical steps such as clinical study design, sample collection, data integration, and protein/peptide identification and preservation. These steps should be carefully controlled before confirmation and verification. Therefore, in clinical applications, these biomarkers are potential diagnostic markers. Large-scale investigations are needed and more sensitive and specific detection methods need to be researched.

Golgi-based therapeutics. In addition to biomarker discovery, the functions of the Golgi apparatus and its associated molecules in maintaining cell structural integrity and its central role in membrane trafficking pathways provide possible targets for disease therapy. These targets may be direct, due to genetic disease (Table I), or indirect, as in cancer. Compared to non-transformed and normal cells, cancer cells have morphological and functional changes in the Golgi apparatus that drive invasion and migration in a unique microenvironment. These changes provide therapeutic targets for interventions. A research team developed a bovine serum albumin $\mathrm{pH}$-responsive photothermal ablation agent that preferentially accumulates in the Golgi of cancer cells compared to normal cells due to morphological changes in the Golgi apparatus (162). The agent is activated by the weakly acidic microenvironment of the Golgi in cancer cells for photothermal therapy. In this method, a photothermal ablation agent converts light energy into heat and kills cancer cells with high specificity and minimal invasiveness by hyperpyrexia (162). Another research team developed a prodrug nanoparticle system, which appeared to target the Golgi apparatus and realized retinoic acid release under an acidic environment. The retinoic acid-conjugated chondroitin sulfate could reduce the expression of metastasis-associated proteins by inducing Golgi fragmentation (163). Those findings suggest that the Golgi apparatus is a promising target for the development of novel drugs. A review summarized small molecules as drugs targeting the Golgi apparatus for the treatment of diseases (164), such as LTX-401, inhibitors of Golgi-associated lipid transfer proteins, glucosylceramide synthase inhibitors, O-glycosylation inhibitors, PI4KIIIb inhibitors and inhibitors of ARF activation. Whether these drugs that target the Golgi apparatus can be applied in clinical practice needs to be determined.

\section{Conclusion}

The central role of the Golgi apparatus in critical cell processes such as the transport, processing, and sorting of proteins and lipids has placed it at the forefront of cell science. Several previous studies have suggested that the Golgi apparatus plays a critical role in diseases, particularly in neurodegenerative diseases. However, few studies focus on human diseases caused by mutations in genes encoding Golgi resident proteins and summarize the common features of these genetic diseases. In the present review, we summed up the genetic diseases caused by mutations in genes encoding Golgi resident proteins. By analyzing their pathophysiology, we identified that the majority of genes are involved in membrane trafficking. The nervous system, skin, bone, cartilage, and skeletal muscle are the most sensitive tissues to defective membrane trafficking. It is reasonable to hope that our basic knowledge of Golgi-mediated membrane trafficking will continue to provide insights into the pathogenesis of genetic diseases and that studies of these diseases will continue to enhance our understanding of the critical role of the Golgi apparatus in diseases. In addition, the finding of Golgi-related biomarker and Golgi-based therapeutics further emphasize the importance of Golgi apparatus in human pathology. Taken together, advances in Golgi apparatus biology provide opportunities to translate discoveries into clinical medicine. Thus, we highlighted the importance of underlying clinical insights and provided a new direction for future research.

\section{Acknowledgements}

Not applicable.

\section{Funding}

The present study was supported by grants from the National Natural Science Foundation of China (grant no. 81974213).

\section{Availability of data and materials}

Not applicable. 


\section{Authors' contributions}

$\mathrm{JL}$ and $\mathrm{YH}$ were mainly responsible for collecting relevant information and completing this review. ZJ, LZ and TL were mainly responsible for consulting literature materials and revising the manuscript. $\mathrm{ZH}$ was responsible for the conception of this review and the assignment of tasks. There was no additional assistance with manuscript preparation. All authors read and approved the final manuscript.

\section{Ethics approval and consent to participate}

Not applicable.

\section{Patient consent for publication}

Not applicable.

\section{Competing interests}

The authors declare that they have no competing interests.

\section{References}

1. Rios RM and Bornens M: The Golgi apparatus at the cell centre. Curr Opin Cell Biol 15: 60-66, 2003.

2. Gautam M, Jara JH, Sekerkova G, Yasvoina MV, Martina M and Özdinler PH: Absence of alsin function leads to corticospinal motor neuron vulnerability via novel disease mechanisms. Hum Mol Genet 25: 1074-1087, 2016.

3. Rendón WO, Martínez-Alonso E, Tomás M, Martínez-Martínez N and Martínez-Menárguez JA: Golgi fragmentation is Rab and SNARE dependent in cellular models of Parkinson's disease. Histochem Cell Biol 139: 671-684, 2013.

4. Brandstaetter H, Kruppa AJ and Buss F: Huntingtin is required for ER-to-Golgi transport and for secretory vesicle fusion at the plasma membrane. Dis Model Mech 7: 1335-1340, 2014.

5. Yuan D, Liu C and Hu B: Dysfunction of membrane trafficking leads to ischemia-reperfusion injury after transient cerebral ischemia. Transl Stroke Res 9: 215-222, 2018.

6. Li T, You H, Mo X, He W, Tang X, Jiang Z, Chen S, Chen Y, Zhang J and Hu Z: GOLPH3 mediated Golgi stress response in modulating N2A cell death upon oxygen-glucose deprivation and reoxygenation injury. Mol Neurobiol 53: 1377-1385, 2016.

7. Tarazón E, Roselló-Lletí E, Ortega A, Gil-Cayuela C, González-Juanatey JR, Lago F, Martínez-Dolz L, Portolés M and Rivera M: Changes in human Golgi apparatus reflect new left ventricular dimensions and function in dilated cardiomyopathy patients. Eur J Heart Fail 19: 280-282, 2017.

8. Stancu CS, Toma L and Sima AV: Dual role of lipoproteins in endothelial cell dysfunction in atherosclerosis. Cell Tissue Res 349: 433-446, 2012.

9. Lee J, Reich R, Xu F and Sehgal PB: Golgi, trafficking, and mitosis dysfunctions in pulmonary arterial endothelial cells exposed to monocrotaline pyrrole and NO scavenging. Am J Physiol Lung Cell Mol Physiol 297: L715-L728, 2009.

10. Sehgal PB, Mukhopadhyay S, Xu F, Patel K and Shah M: Dysfunction of Golgi tethers, SNAREs, and SNAPs in monocrotaline-induced pulmonary hypertension. Am J Physiol Lung Cell Mol Physiol 292: L1526-L1542, 2007.

11. Zhu H, Li H, Wang P, Chen M, Huang Z, Li K, Li Y, He J, Han J and Zhang Q: Persistent and acute chlamydial infections induce different structural changes in the Golgi apparatus. Int J Med Microbiol 304: 577-585, 2014.

12. Rohde J, Emschermann F, Knittler MR and Rziha HJ: Orf virus interferes with MHC class I surface expression by targeting vesicular transport and Golgi. BMC Vet Res 8: 114, 2012.

13. Mousnier A, Swieboda D, Pinto A, Guedán A, Rogers AV, Walton R, Johnston SL and Solari R: Human rhinovirus 16 causes Golgi apparatus fragmentation without blocking protein secretion. J Virol 88: 11671-11685, 2014.
14. Tan X, Banerjee P, Guo HF, Ireland S, Pankova D, Ahn YH, Nikolaidis IM, Liu X, Zhao Y, Xue Y, et al: Epithelial-tomesenchymal transition drives a pro-metastatic Golgi compaction process through scaffolding protein PAQR11. J Clin Invest 127: 117-131, 2017.

15. Golgi C: On the structure of nerve cells. 1898. J Microsc 155: 3-7, 1989.

16. Mollenhauer HH and Morré DJ: Perspectives on Golgi apparatus form and function. J Electron Microsc Tech 17: 2-14, 1991.

17. Storrie B, White J, Röttger S, Stelzer EH, Suganuma T and Nilsson T: Recycling of golgi-resident glycosyltransferases through the ER reveals a novel pathway and provides an explanation for nocodazole-induced Golgi scattering. J Cell Biol 143: 1505-1521, 1998.

18. Slusarewicz P, Nilsson T, Hui N, Watson R and Warren G: Isolation of a matrix that binds medial Golgi enzymes. J Cell Biol 124: 405-413, 1994.

19. Papanikou E and Glick BS: Golgi compartmentation and identity. Curr Opin Cell Biol 29: 74-81, 2014

20. Glick BS and Luini A: Models for Golgi traffic: A critical assessment. Cold Spring Harb Perspect Biol 3: a005215, 2011.

21. Sundaramoorthy V, Sultana JM and Atkin JD: Golgi fragmentation in amyotrophic lateral sclerosis, an overview of possible triggers and consequences. Front Neurosci 9: 400, 2015.

22. Gonatas NK, Stieber A and Gonatas JO: Fragmentation of the Golgi apparatus in neurodegenerative diseases and cell death. J Neurol Sci 246: 21-30, 2006.

23. Jiang Z, Hu Z, Zeng L, Lu W, Zhang H, Li T and Xiao H: The role of the Golgi apparatus in oxidative stress: Is this organelle less significant than mitochondria? Free Radic Biol Med 50: 907-917, 2011.

24. Liu JY, He JL, Huang Y, Xiao H, Jiang Z and Hu ZP: The Golgi apparatus in neurorestoration. J Neuroresstoratology 7: 116-128, 2019.

25. Fan J, Hu Z, Zeng L, Lu W, Tang X, Zhang J and Li T: Golgi apparatus and neurodegenerative diseases. Int J Dev Neurosci 26: 523-534, 2008.

26. Lu L, Zhou Q, Chen Z and Chen L: The significant role of the Golgi apparatus in cardiovascular diseases. J Cell Physiol 233: 2911-2919, 2018

27. Millarte V and Farhan H: The Golgi in cell migration: Regulation by signal transduction and its implications for cancer cell metastasis. ScientificWorldJournal 2012: 498278, 2012.

28. Mourelatos Z, Gonatas NK, Stieber A, Gurney ME and Dal Canto MC: The Golgi apparatus of spinal cord motor neurons in transgenic mice expressing mutant $\mathrm{Cu}, \mathrm{Zn}$ superoxide dismutase becomes fragmented in early, preclinical stages of the disease. Proc Natl Acad Sci USA 93: 5472-5477, 1996.

29. Joshi G, Bekier ME II and Wang Y: Golgi fragmentation in Alzheimer's disease. Front Neurosci 9: 340, 2015.

30. Strehlow AN, Li JZ and Myers RM: Wild-type huntingtin participates in protein trafficking between the Golgi and the extracellular space. Hum Mol Genet 16: 391-409, 2007.

31. Sakurai A, Okamoto K, Fujita Y, Nakazato Y, Wakabayashi K, Takahashi $\mathrm{H}$ and Gonatas NK: Fragmentation of the Golgi apparatus of the ballooned neurons in patients with corticobasal degeneration and Creutzfeldt-Jakob disease. Acta Neuropathol 100: 270-274, 2000.

32. Sakurai A, Okamoto K, Yaguchi M, Fujita Y, Mizuno Y, Nakazato $Y$ and Gonatas NK: Pathology of the inferior olivary nucleus in patients with multiple system atrophy. Acta Neuropathol 103: 550-554, 2002.

33. van Dis V, Kuijpers M, Haasdijk ED, Teuling E, Oakes SA, Hoogenraad CC and Jaarsma D: Golgi fragmentation precedes neuromuscular denervation and is associated with endosome abnormalities in SOD1-ALS mouse motor neurons. Acta Neuropathol Commun 2: 38, 2014.

34. Pottorf T, Mann A, Fross S, Mansel C and Vohra BPS: Nicotinamide mononucleotide adenylyltransferase 2 maintains neuronal structural integrity through the maintenance of golgi structure. Neurochem Int 121: 86-97, 2018.

35. Joshi G and Wang Y: Golgi defects enhance APP amyloidogenic processing in Alzheimer's disease. Bioessays 37: 240-247, 2015.

36. Covarrubias-Pinto A, Parra AV, Mayorga-Weber G, Papic E, Vicencio I, Ehrenfeld P, Rivera FJ and Castro MA: Impaired intracellular trafficking of sodium-dependent vitamin $C$ transporter 2 contributes to the redox imbalance in Huntington's disease. J Neurosci Res 99: 223-235, 2021. 
37. Mani M, Thao DT, Kim BC, Lee UH, Kim DJ, Jang SH, Back SH, Lee BJ, Cho WJ, Han IS and Park JW: DRG2 knockdown induces Golgi fragmentation via GSK3 $\beta$ phosphorylation and microtubule stabilization. Biochim Biophys Acta Mol Cell Res 1866: 1463-1474, 2019.

38. Rodríguez-Cruz F, Torres-Cruz FM, Monroy-Ramírez HC, Escobar-Herrera J, Basurto-Islas G, Avila J and García-Sierra F: Fragmentation of the Golgi apparatus in neuroblastoma cells is associated with tau-induced ring-shaped microtubule bundles J Alzheimers Dis 65: 1185-1207, 2018.

39. Sou YS, Kakuta S, Kamikubo Y, Niisato K, Sakurai T, Parajuli LK, Tanida I, Saito H, Suzuki N, Sakimura K, et al: Cerebellar neurodegeneration and neuronal circuit remodeling in Golgi $\mathrm{pH}$ regulator-deficient mice. eNeuro 6: ENEURO.0427-18.2019, 2019.

40. Heuer D, Rejman Lipinski A, Machuy N, Karlas A, Wehrens A, Siedler F, Brinkmann V and Meyer TF: Chlamydia causes fragmentation of the Golgi compartment to ensure reproduction. Nature 457: 731-735, 2009.

41. Pruneda JN, Bastidas RJ, Bertsoulaki E, Swatek KN Santhanam B, Clague MJ, Valdivia RH, Urbé S and Komander D A chlamydia effector combining deubiquitination and acetylation activities induces Golgi fragmentation. Nat Microbiol 3 : 1377-1384, 2018.

42. Hansen MD, Johnsen IB, Stiberg KA, Sherstova T, Wakita T, Richard GM, Kandasamy RK, Meurs EF and Anthonsen MW: Hepatitis $\mathrm{C}$ virus triggers Golgi fragmentation and autophagy through the immunity-related GTPase M. Proc Natl Acad Sci USA 114: E3462-E3471, 2017.

43. Aistleitner K, Clark T, Dooley C and Hackstadt T: Selective fragmentation of the trans-Golgi apparatus by Rickettsia rickettsii. PLoS Pathog 16: e1008582, 2020.

44. Ganesan M, Mathews S, Makarov E, Petrosyan A Kharbanda KK, Kidambi S, Poluektova LY, Casey CA and Osna NA: Acetaldehyde suppresses HBV-MHC class I complex presentation on hepatocytes via induction of ER stress and Golgi fragmentation. Am J Physiol Gastrointest Liver Physiol 319: G432-G442, 2020

45. Quiner CA and Jackson WT: Fragmentation of the Golgi apparatus provides replication membranes for human rhinovirus $1 \mathrm{~A}$ Virology 407: 185-195, 2010

46. Barbosa NS, Mendonca LR, Dias MVS, Pontelli MC, da Silva EZM, Criado MF, da Silva-Januário ME, Schindler M, Jamur MC, Oliver C, et al: ESCRT machinery components are required for orthobunyavirus particle production in Golgi compartments. PLoS Pathog 14: e1007047, 2018.

47. Petrosyan A, Holzapfel MS, Muirhead DE and Cheng PW: Restoration of compact Golgi morphology in advanced prostate cancer enhances susceptibility to galectin-1-induced apoptosis by modifying mucin O-glycan synthesis. Mol Cancer Res 12 : $1704-1716,2014$

48. Tokuda E, Itoh T, Hasegawa J, Ijuin T, Takeuchi Y, Irino Y, Fukumoto $M$ and Takenawa T: Phosphatidylinositol 4-phosphate in the Golgi apparatus regulates cell-cell adhesion and invasive cell migration in human breast cancer. Cancer Res 74: 3054-3066, 2014

49. Zhao J, Yang C, Guo S and Wu Y: GM130 regulates epithelial-to-mesenchymal transition and invasion of gastric cancer cells via snail. Int J Clin Exp Pathol 8: 10784-10791, 2015.

50. Pinho SS and Reis CA: Glycosylation in cancer: Mechanisms and clinical implications. Nat Rev Cancer 15: 540-555, 2015.

51. Pinho SS, Seruca R, Gärtner F, Yamaguchi Y, Gu J, Taniguchi N and Reis CA: Modulation of E-cadherin function and dysfunction by N-glycosylation. Cell Mol Life Sci 68: 1011-1020, 2011.

52. Baschieri F, Confalonieri S, Bertalot G, Di Fiore PP, Dietmaier W, Leist M, Crespo P, Macara IG and Farhan H: Spatial control of Cdc42 signalling by a GM130-RasGRF complex regulates polarity and tumorigenesis. Nat Commun 5: 4839, 2014.

53. Taniguchi $\mathrm{N}$ and Kizuka Y: Glycans and cancer: Role of $\mathrm{N}$-glycans in cancer biomarker, progression and metastasis, and therapeutics. Adv Cancer Res 126: 11-51, 2015.

54. Rizzo R, Parashuraman S, D'Angelo G and Luini A: GOLPH3 and oncogenesis: What is the molecular link? Tissue Cell 49: 170-174, 2017.

55. Farber-Katz SE, Dippold HC, Buschman MD, Peterman MC, Xing M, Noakes CJ, Tat J, Ng MM, Rahajeng J, Cowan DM, et al DNA damage triggers Golgi dispersal via DNA-PK and GOLPH3. Cell 156: 413-427, 2014.

56. Scott KL, Kabbarah O, Liang MC, Ivanova E, Anagnostou V, Wu J, Dhakal S, Wu M, Chen S, Feinberg T, et al: GOLPH3 modulates mTOR signalling and rapamycin sensitivity in cancer. Nature 459: 1085-1090, 2009.
57. Xing M, Peterman MC, Davis RL, Oegema K, Shiau AK and Field SJ: GOLPH3 drives cell migration by promoting Golgi reorientation and directional trafficking to the leading edge. Mol Biol Cell 27: 3828-3840, 2016.

58. Chang SH, Hong SH, Jiang HL, Minai-Tehrani A, Yu KN, Lee JH, Kim JE, Shin JY, Kang B, Park S, et al: GOLGA2/GM130, cis-Golgi matrix protein, is a novel target of anticancer gene therapy. Mol Ther 20: 2052-2063, 2012

59. Sehgal PB, Mukhopadhyay S, Patel K, Xu F, Almodóvar S, Tuder RM and Flores SC: Golgi dysfunction is a common feature in idiopathic human pulmonary hypertension and vascular lesions in SHIV-nef-infected macaques. Am J Physiol Lung Cell Mol Physiol 297: L729-L737, 2009.

60. Sehgal PB and Lee JE: Protein trafficking dysfunctions: Role in the pathogenesis of pulmonary arterial hypertension. Pulm Circ 1: 17-32, 2011

61. Muhammad E, Levitas A, Singh SR, Braiman A, Ofir R, Etzion S, Sheffield VC, Etzion Y, Carrier L and Parvari R: PLEKHM2 mutation leads to abnormal localization of lysosomes, impaired autophagy flux and associates with recessive dilated cardiomyopathy and left ventricular noncompaction. Hum Mol Genet 24 : 7227-7240, 2015 .

62. Hatt PY: Cellular changes and damage in mechanically overloaded hearts. Recent Adv Stud Cardiac Struct Metab 6: 325-333, 1975.

63. Satoh H: Sino-atrial nodal cells of mammalian hearts: Ionic currents and gene expression of pacemaker ionic channels. J Smooth Muscle Res 39: 175-193, 2003.

64. Jungk L, Franke H, Salameh A and Dhein S: Golgi fragmentation in human patients with chronic atrial fibrillation: A new aspect of remodeling. Thorac Cardiovasc Surg 67: 98-106, 2019.

65. Prasad K and Singal PK: Ultrastructure of failing myocardium due to induced chronic mitral insufficiency in dogs. Br J Exp Pathol 58: 289-300, 1977

66. Rambourg A, Clermont $\mathrm{Y}$ and Hermo L: Three-dimensional architecture of the golgi apparatus in sertoli cells of the rat. Am J Anat 154: 455-476, 1979.

67. Xiang Y and Wang Y: New components of the Golgi matrix. Cell Tissue Res 344: 365-379, 2011

68. Kooy J, Toh BH, Pettitt JM, Erlich R and Gleeson PA: Human autoantibodies as reagents to conserved Golgi components. Characterization of a peripheral, 230-kDa compartment-specific Golgi protein. J Biol Chem 267: 20255-20263, 1992.

69. Fritzler MJ, Hamel JC, Ochs RL and Chan EK: Molecular characterization of two human autoantigens: Unique cDNAs encoding $95-$ and $160-\mathrm{kD}$ proteins of a putative family in the Golgi complex. J Exp Med 178: 49-62, 1993.

70. Wong M and Munro S: Membrane trafficking. The specificity of vesicle traffic to the Golgi is encoded in the golgin coiled-coil proteins. Science 346: 1256898, 2014

71. Barr FA, Puype M, Vandekerckhove J and Warren G: GRASP65, a protein involved in the stacking of Golgi cisternae. Cell 91: 253-262, 1997.

72. Shorter J and Warren G: A role for the vesicle tethering protein, p115, in the post-mitotic stacking of reassembling Golgi cisternae in a cell-free system. J Cell Biol 146: 57-70, 1999.

73. Vinke FP, Grieve AG and Rabouille C: The multiple facets of the Golgi reassembly stacking proteins. Biochem J 433: 423-433, 2011

74. Bergen DJM, Stevenson NL, Skinner REH, Stephens DJ and Hammond CL: The Golgi matrix protein giantin is required for normal cilia function in zebrafish. Biol Open 6: 1180-1189, 2017.

75. Hennies HC, Kornak U, Zhang H, Egerer J, Zhang X, Seifert W, Kühnisch J, Budde B, Nätebus M, Brancati F, et al: Gerodermia osteodysplastica is caused by mutations in SCYL1BP1, a Rab-6 interacting golgin. Nat Genet 40: 1410-1412, 2008.

76. Nakamura N, Rabouille C, Watson R, Nilsson T, Hui N, Slusarewicz P, Kreis TE and Warren G: Characterization of a cis-Golgi matrix protein, GM130. J Cell Biol 131: 1715-1726, 1995.

77. Alvarez C, Garcia-Mata R, Hauri HP and Sztul E: The p115-interactive proteins GM130 and giantin participate in endoplasmic reticulum-Golgi traffic. J Biol Chem 276: 2693-2700, 2001.

78. Huang W, She L, Chang XY, Yang RR, Wang L, Ji HB, Jiao JW and Poo MM: Protein kinase LKB1 regulates polarized dendrite formation of adult hippocampal newborn neurons. Proc Nat Acad Sci USA 111: 469-474, 2014.

79. Liu C, Mei M, Li Q, Roboti P, Pang Q, Ying Z, Gao F, Lowe M and Bao S: Loss of the golgin GM130 causes Golgi disruption, Purkinje neuron loss, and ataxia in mice. Proc Natl Acad Sci USA 114: 346-351, 2017 
80. Matanis T, Akhmanova A, Wulf P, Del Nery E, Weide T, Stepanova T, Galjart N, Grosveld F, Goud B, De Zeeuw CI, et al: Bicaudal-D regulates COPI-independent Golgi-ER transport by recruiting the dynein-dynactin motor complex. Nat Cell Biol 4: 986-992, 2002.

81. Hoogenraad CC, Akhmanova A, Howell SA, Dortland BR De Zeeuw CI, Willemsen R, Visser P, Grosveld F and Galjart N: Mammalian Golgi-associated Bicaudal-D2 functions in the dynein-dynactin pathway by interacting with these complexes. EMBO J 20: 4041-4054, 2001.

82. Jaarsma D, van den Berg R, Wulf PS, van Erp S, Keijzer N, Schlager MA, de Graaff E, De Zeeuw CI, Pasterkamp RJ, Akhmanova A and Hoogenraad CC: A role for bicaudal-D2 in radial cerebellar granule cell migration. Nat Commun 5: 3411, 2014.

83. Will L, Portegies S, van Schelt J, van Luyk M, Jaarsma D and Hoogenraad CC: Dynein activating adaptor BICD2 controls radial migration of upper-layer cortical neurons in vivo. Acta Neuropathol Commun 7: 162, 2019.

84. Storbeck M, Horsberg Eriksen B, Unger A, Hölker I, Aukrust I, Martínez-Carrera LA, Linke WA, Ferbert A, Heller R, Vorgerd M, et al: Phenotypic extremes of BICD2-opathies: From lethal, congenital muscular atrophy with arthrogryposis to asymptomatic with subclinical features. Eur J Hum Genet 25 : 1040-1048, 2017.

85. Neveling K, Martinez-Carrera LA, Hölker I, Heister A, Verrips A, Hosseini-Barkooie SM, Gilissen C, Vermeer S, Pennings M, Meijer R, et al: Mutations in BICD2, which encodes a golgin and important motor adaptor, cause congenital autosomal-dominant spinal muscular atrophy. Am J Hum Genet 92: 946-954, 2013.

86. Oates EC, Rossor AM, Hafezparast M, Gonzalez M, Speziani F, MacArthur DG, Lek M, Cottenie E, Scoto M, Foley AR, et al: Mutations in BICD2 cause dominant congenital spinal muscular atrophy and hereditary spastic paraplegia. Am J Hum Genet 92: 965-973, 2013.

87. Sonnichsen B, Lowe M, Levine T, Jämsä E, Dirac-Svejstrup B and Warren G: A role for giantin in docking COPI vesicles to Golgi membranes. J Cell Biol 140: 1013-1021, 1998

88. Katayama K, Kuriki M, Kamiya T, Tochigi Y and Suzuki H: Giantin is required for coordinated production of aggrecan, link protein and type XI collagen during chondrogenesis. Biochem Biophys Res Commun 499: 459-465, 2018.

89. Stevenson NL, Bergen DJM, Skinner REH, Kague E Martin-Silverstone E, Robson Brown KA, Hammond CL and Stephens DJ: Giantin-knockout models reveal a feedback loop between Golgi function and glycosyltransferase expression. J Cell Sci 130: 4132-4143, 2017.

90. Witkos TM, Chan WL, Joensuu M, Rhiel M, Pallister E, Thomas-Oates J, Mould AP, Mironov AA, Biot C, Guerardel Y, et al: GORAB scaffolds COPI at the trans-Golgi for efficient enzyme recycling and correct protein glycosylation. Nat Commun 10: 127, 2019.

91. Sato K, Roboti P, Mironov AA and Lowe M: Coupling of vesicle tethering and Rab binding is required for in vivo functionality of the golgin GMAP-210. Mol Biol Cell 26: 537-553, 2015.

92. Smits P, Bolton AD, Funari V, Hong M, Boyden ED, Lu L, Manning DK, Dwyer ND, Moran JL, Prysak M, et al: Lethal skeletal dysplasia in mice and humans lacking the golgin GMAP-210. N Engl J Med 362: 206-216, 2010.

93. Wehrle A, Witkos TM, Unger S, Schneider J, Follit JA, Hermann J, Welting T, Fano V, Hietala M, Vatanavicharn N, et al Hypomorphic mutations of TRIP11 cause odontochondrodysplasia. JCI Insight 4: e124701, 2019.

94. West DW: Energy-dependent calcium sequestration activity in a Golgi apparatus fraction derived from lactating rat mammary glands. Biochim Biophys Acta 673: 374-386, 1981.

95. Shull GE, Miller ML and Prasad V: Secretory pathway stress responses as possible mechanisms of disease involving Golgi $\mathrm{Ca}^{2+}$ pump dysfunction. Biofactors 37: 150-158, 2011.

96. Sudbrak R, Brown J, Dobson-Stone C, Carter S, Ramser J, White J, Healy E, Dissanayake M, Larrègue M, Perrussel M, et al: Hailey-Hailey disease is caused by mutations in ATP2C1 encoding a novel $\mathrm{Ca}(2+)$ pump. Hum Mol Genet 9: 1131-1140, 2000.

97. Hu Z, Bonifas JM, Beech J, Bench G, Shigihara T, Ogawa H, Ikeda S, Mauro T and Epstein EH Jr: Mutations in ATP2C1, encoding a calcium pump, cause Hailey-Hailey disease. Nat Genet 24: 61-65, 2000
98. Okunade GW, Miller ML, Azhar M, Andringa A, Sanford LP, Doetschman T, Prasad V and Shull GE: Loss of the Atp2c1 secretory pathway $\mathrm{Ca}(2+)$-ATPase (SPCA1) in mice causes Golgi stress, apoptosis, and midgestational death in homozygous embryos and squamous cell tumors in adult heterozygotes. J Biol Chem 282: 26517-26527, 2007.

99. Lázaro-Diéguez F, Jiménez N, Barth H, Koster AJ, Renau-Piqueras J, Llopis JL, Burger KN and Egea G: Actin filaments are involved in the maintenance of Golgi cisternae morphology and intra-Golgi pH. Cell Motil Cytoskeleton 63: 778-791, 2006.

100. Huang $\mathrm{C}$ and Chang $\mathrm{A}$ : $\mathrm{pH}-$ dependent cargo sorting from the Golgi. J Biol Chem 286: 10058-10065, 2011.

101. Rivinoja A, Pujol FM, Hassinen A and Kellokumpu S: Golgi pH, its regulation and roles in human disease. Ann Med 44: 542-554, 2012.

102. Drory O and Nelson $\mathrm{N}$ : The emerging structure of vacuolar ATPases. Physiology (Bethesda) 21: 317-325, 2006

103. Maeda Y, Ide T, Koike M, Uchiyama Y and Kinoshita T: GPHR is a novel anion channel critical for acidification and functions of the Golgi apparatus. Nat Cell Biol 10: 1135-1145, 2008.

104. Banerjee S and Kane PM: Regulation of V-ATPase activity and organelle $\mathrm{pH}$ by phosphatidylinositol phosphate lipids. Front Cell Dev Biol 8: 510, 2020.

105. Morava E, Guillard M, Lefeber DJ and Wevers RA: Autosomal recessive cutis laxa syndrome revisited. Eur J Hum Genet 17: 1099-1110, 2009.

106. Van Damme T, Gardeitchik T, Mohamed M, Guerrero-Castillo S, Freisinger P, Guillemyn B, Kariminejad A, Dalloyaux D, van Kraaij S, Lefeber DJ, et al: Mutations in ATP6V1E1 or ATP6V1A cause autosomal-recessive cutis laxa. Am J Hum Genet 100: 216-227, 2017.

107. Kariminejad A, Afroozan F, Bozorgmehr B, Ghanadan A, Akbaroghli S, Khorram Khorshid HR, Mojahedi F, Setoodeh A, Loh A, Tan YX, et al: Discriminative features in three autosomal recessive cutis laxa syndromes: Cutis laxa IIA, cutis laxa IIB, and geroderma osteoplastica. Int J Mol Sci 18: 635, 2017.

108. Kornak U, Reynders E, Dimopoulou A, van Reeuwijk J, Fischer B, Rajab A, Budde B, Nürnberg P, Foulquier F; ARCL Debré-type Study Group, et al: Impaired glycosylation and cutis laxa caused by mutations in the vesicular H+-ATPase subunit ATP6V0A2. Nat Genet 40: 32-34, 2008.

109. Tümer Z: An overview and update of ATP7A mutations leading to Menkes disease and occipital horn syndrome. Hum Mutat 34 417-429, 2013

110. Huster D, Hoppert M, Lutsenko S, Zinke J, Lehmann C, Mössner J, Berr F and Caca K: Defective cellular localization of mutant ATP7B in Wilson's disease patients and hepatoma cell lines. Gastroenterology 124: 335-345, 2003.

111. Guan JL, Machamer CE and Rose JK: Glycosylation allows cell-surface transport of an anchored secretory protein. Cell 42: 489-496, 1985

112. Roth J: Protein N-glycosylation along the secretory pathway: Relationship to organelle topography and function, protein quality control, and cell interactions. Chem Rev 102: 285-303, 2002.

113. Rosnoblet C, Peanne R, Legrand D and Foulquier F: Glycosylation disorders of membrane trafficking. Glycoconj J 30: 23-31, 2013

114. Grewal PK, McLaughlan JM, Moore CJ, Browning CA and Hewitt JE: Characterization of the LARGE family of putative glycosyltransferases associated with dystroglycanopathies. Glycobiology 15: 912-923, 2005

115. Kobayashi K, Nakahori Y, Miyake M, Matsumura K, Kondo-Iida E, Nomura Y, Segawa M, Yoshioka M, Saito K, Osawa M, et al: An ancient retrotransposal insertion causes Fukuyama-type congenital muscular dystrophy. Nature 394: 388-392, 1998

116. Brockington M, Blake DJ, Prandini P, Brown SC, Torelli S, Benson MA, Ponting CP, Estournet B, Romero NB, Mercuri E, et al: Mutations in the fukutin-related protein gene (FKRP) cause a form of congenital muscular dystrophy with secondary laminin alpha2 deficiency and abnormal glycosylation of alpha-dystroglycan. Am J Hum Genet 69: 1198-1209, 2001.

117. Desplats PA, Denny CA, Kass KE, Gilmartin T, Head SR, Sutcliffe JG, Seyfried TN and Thomas EA: Glycolipid and ganglioside metabolism imbalances in Huntington's disease. Neurobiol Dis 27: 265-277, 2007. 
118. Cooper-Knock J, Moll T, Ramesh T, Castelli L, Beer A, Robins H, Fox I, Niedermoser I, Van Damme P, Moisse M, et al: Mutations in the glycosyltransferase domain of GLT8D1 are associated with familial amyotrophic lateral sclerosis. Cell Rep 26: 2298-2306.e5, 2019.

119. Li W, Liu Z, Sun W, Yuan Y, Hu Y, Ni J, Jiao B, Fang L, Li J, Shen L, et al: Mutation analysis of GLT8D1 and ARPP21 genes in amyotrophic lateral sclerosis patients from mainland China. Neurobiol Aging 85: 156.e1-156.e4, 2020.

120. Liu S and Storrie B: Are Rab proteins the link between Golgi organization and membrane trafficking? Cell Mol Life Sci 69: 4093-4106, 2012.

121. Salian S, Cho TJ, Phadke SR, Gowrishankar K, Bhavani GS, Shukla A, Jagadeesh S, Kim OH, Nishimura G and Girisha KM: Additional three patients with Smith-McCort dysplasia due to novel RAB33B mutations. Am J Med Genet A 173: 588-595, 2017.

122. Giannandrea M, Bianchi V, Mignogna ML, Sirri A, Carrabino S, D'Elia E, Vecellio M, Russo S, Cogliati F, Larizza L, et al: Mutations in the small GTPase gene RAB39B are responsible for X-linked mental retardation associated with autism, epilepsy, and macrocephaly. Am J Hum Genet 86: 185-195, 2010.

123. Bock JB, Matern HT, Peden AA and Scheller RH: A genomic perspective on membrane compartment organization. Nature 409: 839-841, 2001.

124. Corbett MA, Schwake M, Bahlo M, Dibbens LM, Lin M, Gandolfo LC, Vears DF, O'Sullivan JD, Robertson T, Bayly MA, et al: A mutation in the Golgi Qb-SNARE gene GOSR 2 causes progressive myoclonus epilepsy with early ataxia. Am J Hum Genet 88: 657-663, 2011.

125. Lowe SL, Peter F, Subramaniam VN, Wong SH and Hong W: A SNARE involved in protein transport through the Golgi apparatus. Nature 389: 881-884, 1997.

126. Malsam J and Söllner TH: Organization of SNAREs within the Golgi stack. Cold Spring Harb Perspect Biol 3: a005249, 2011

127. Gedeon AK, Colley A, Jamieson R, Thompson EM, Rogers J, Sillence D, Tiller GE, Mulley JC and Gécz J: Identification of the gene (SEDL) causing X-linked spondyloepiphyseal dysplasia tarda. Nat Genet 22: 400-404, 1999.

128. Willett R, Ungar D and Lupashin V: The Golgi puppet master: COG complex at center stage of membrane trafficking interactions. Histochem Cell Biol 140: 271-283, 2013.

129. Climer LK, Dobretsov M and Lupashin V: Defects in the COG complex and COG-related trafficking regulators affect neuronal Golgi function. Front Neurosci 9: 405, 2015

130. Miller VJ and Ungar D: Re'COG'nition at the Golgi. Traffic 13: 891-897, 2012

131. Egorov MV, Capestrano M, Vorontsova OA, Di Pentima A, Egorova AV, Mariggiò S, Ayala MI, Tetè S, Gorski JL, Luini A, et al: Faciogenital dysplasia protein (FGD1) regulates export of cargo proteins from the golgi complex via Cdc42 activation. Mol Biol Cell 20: 2413-2427, 2009.

132. Roboti P, Sato K and Lowe M: The golgin GMAP-210 is required for efficient membrane trafficking in the early secretory pathway. J Cell Sci 128: 1595-1606, 2015

133. Zhang $\mathrm{H}$, Winckler B and Cai Q: Introduction to the special issue on membrane trafficking in neurons. Dev Neurobiol 78: $167-169,2018$

134. Rosnoblet C, Legrand D, Demaegd D, Hacine-Gherbi H, de Bettignies G, Bammens R, Borrego C, Duvet S, Morsomme P, Matthijs $\mathrm{G}$ and Foulquier F: Impact of disease-causing mutations on TMEM165 subcellular localization, a recently identified protein involved in CDG-II. Hum Mol Genet 22: 2914-2928, 2013

135. Larson AA, Baker PR II, Milev MP, Press CA, Sokol RJ, Cox MO, Lekostaj JK, Stence AA, Bossler AD, Mueller JM, et al: TRAPPC11 and GOSR2 mutations associate with hypoglycosylation of $\alpha$-dystroglycan and muscular dystrophy. Skelet Muscle 8: 17, 2018.

136. Davis EE, Savage JH, Willer JR, Jiang YH, Angrist M, Androutsopoulos A and Katsanis N: Whole exome sequencing and functional studies identify an intronic mutation in TRAPPC2 that causes SEDT. Clin Genet 85: 359-364, 2014.

137. Riener MO: Diagnosis of tumours of the liver and the biliary tract: New tissue and serum markers. Pathologe 32 (Suppl 2): S304-S309, 2011 (In German).

138. Xu Z, Liu L, Pan X, Wei K, Wei M, Liu L, Yang H and Liu Q: Serum Golgi protein 73 (GP73) is a diagnostic and prognostic marker of chronic HBV liver disease. Medicine (Baltimore) 94: e659, 2015.
139. Liu Y, Zou Z, Zhu B, Hu Z and Zeng P: CXCL10 decreases GP73 expression in hepatoma cells at the early stage of hepatitis C virus (HCV) infection. Int J Mol Sci 14: 24230-24241, 2013.

140. Zheng KI, Liu WY, Pan XY, Ma HL, Zhu PW, Wu XX, Targher G, Byrne C, Wang XD, Chen YP, et al: Combined and sequential non-invasive approach to diagnosing non-alcoholic steatohepatitis in patients with non-alcoholic fatty liver disease and persistently normal alanine aminotransferase levels. BMJ Open Diabetes Res Care 8: e001174, 2020.

141. Hou SC, Xiao MB, Ni RZ, Ni WK, Jiang F, Li XY, Lu CH and Chen BY: Serum GP73 is complementary to AFP and GGT-II for the diagnosis of hepatocellular carcinoma. Oncol Lett 6 : $1152-1158,2013$

142. Zhao J, Guo LY, Yang JM and Jia JW: Sublingual vein parameters, AFP, AFP-L3, and GP73 in patients with hepatocellular carcinoma. Genet Mol Res 14: 7062-7067, 2015.

143. Liu X, Wan X, Li Z, Lin C, Zhan Y and Lu X: Golgi protein 73(GP73), a useful serum marker in liver diseases. Clin Chem Lab Med 49: 1311-1316, 2011.

144. Morota K, Nakagawa M, Sekiya R, Hemken PM, Sokoll LJ, Elliott D, Chan DW and Dowell BL: A comparative evaluation of Golgi protein-73, fucosylated hemopexin, $\alpha$-fetoprotein, and PIVKA-II in the serum of patients with chronic hepatitis, cirrhosis, and hepatocellular carcinoma. Clin Chem Lab Med 49: 711-718, 2011

145. Gu Y, Chen W, Zhao Y, Chen L and Peng T: Quantitative analysis of elevated serum Golgi protein-73 expression in patients with liver diseases. Ann Clin Biochem 46: 38-43, 2009.

146. Tian L, Wang Y, Xu D, Gui J, Jia X, Tong H, Wen X, Dong Z and Tian Y: Serological AFP/Golgi protein 73 could be a new diagnostic parameter of hepatic diseases. Int J Cancer 129: 1923-1931, 2011

147. Ye JZ, Yan SM, Yuan CL, Wu HN, Zhang JY, Liu ZH, Li YQ, Luo XL, Lin Y and Liang R: GP73 level determines chemotherapeutic resistance in human hepatocellular carcinoma cells. J Cancer 9: 415-423, 2018.

148. Lebredonchel E, Houdou M, Potelle S, de Bettignies G, Schulz C, Krzewinski Recchi MA, Lupashin V, Legrand D and Klein A, Foulquier F: Dissection of TMEM165 function in Golgi glycosylation and its $\mathrm{Mn}^{2+}$ sensitivity. Biochimie 165: 123-130, 2019

149. Lee JS, Kim MY, Park ER, Shen YN, Jeon JY, Cho EH, Park SH, Han CJ, Choi DW, Jang JJ, et al: TMEM165, a Golgi transmembrane protein, is a novel marker for hepatocellular carcinoma and its depletion impairs invasion activity. Oncol Rep 40: 1297-1306, 2018.

150. Lee SH, Yoo HJ, Rim DE, Cui Y, Lee A, Jung ES, Oh ST, Kim JG, Kwon OJ, Kim SY and Jeong SW: Nuclear expression of GS28 protein: A novel biomarker that predicts prognosis in colorectal cancers. Int J Med Sci 14: 515-522, 2017.

151. Cho U, Kim HM, Park HS, Kwon OJ, Lee A and Jeong SW: Nuclear expression of GS28 protein: A novel biomarker that predicts worse prognosis in cervical cancers. PLoS One 11: e0162623, 2016

152. Rodriguez JL, Gelpi C, Thomson TM, Real FJ and Fernández J: Anti-golgi complex autoantibodies in a patient with Sjögren syndrome and lymphoma. Clin Exp Immunol 49: 579-586, 1982.

153. Fritzler MJ, Etherington J, Sokoluk C, Kinsella TD and Valencia DW: Antibodies from patients with autoimmune disease react with a cytoplasmic antigen in the Golgi apparatus. J Immunol 132: 2904-2908, 1984.

154. Hong HS, Morshed SA, Tanaka S, Fujiwara T, Ikehara Y and Nishioka M: Anti-Golgi antibody in rheumatoid arthritis patients recognizes a novel antigen of $79 \mathrm{kDa}$ (doublet) by western blot. Scand J Immunol 36: 785-792, 1992.

155. Gentric A, Blaschek M, Julien C, Jouquan J, Pennec Y, Berthelot JM, Mottier D, Casburn-Budd R and Youinou P: Nonorgan-specific autoantibodies in individuals infected with type 1 human immunodeficiency virus. Clin Immunol Immunopathol 59: 487-494, 1991.

156. Griffith KJ, Chan EK, Lung CC, Hamel JC, Guo X, Miyachi K and Fritzler MJ: Molecular cloning of a novel 97-kd Golgi complex autoantigen associated with Sjögren's syndrome. Arthritis Rheum 40: 1693-1702, 1997.

157. Gaspar ML, Marcos MA, Gutierrez C, Martin MJ, Bonifacino JS and Sandoval IV: Presence of an autoantibody against a Golgi cisternal membrane protein in the serum and cerebrospinal fluid from a patient with idiopathic late onset cerebellar ataxia. J Neuroimmunol 17: 287-299, 1988 
158. Huidbüchel E, Blaschek M, Seigneurin JM, Lamour A Berthelot JM and Youinou P: Anti-organelle and anti-cytoskeletal autoantibodies in the serum of Epstein-Barr virus-infected patients. Ann Med Interne (Paris) 142: 343-346, 1991.

159. Paraná R, Schinoni MI, de Freitas LA, Codes L, Cruz M, Andrade $\mathrm{Z}$ and Trepo C: Anti-Golgi complex antibodies during pegylated-interferon therapy for hepatitis C. Liver Int 26: $1148-1154,2006$

160. Mozo L, Simó A, Suarez A, Rodrigo L and Gutiérrez C: Autoantibodies to Golgi proteins in hepatocellular carcinoma: Case report and literature review. Eur J Gastroenterol Hepatol 14: 771-774, 2002.

161. Fritzler MJ,Hudson M, Choi MY, Mahler M, Wang M, Bentow C, Milo J and Baron M; Canadian Scleroderma Research Group: Bicaudal D2 is a novel autoantibody target in systemic sclerosis that shares a key epitope with CENP-A but has a distinct clinical phenotype. Autoimmun Rev 17: 267-275, 2018.

162. Xue F, Wen Y, Wei P, Gao Y, Zhou Z, Xiao S and Yi T: A smart drug: A pH-responsive photothermal ablation agent for Golgi apparatus activated cancer therapy. Chem Commun (Camb) 53 : 6424-6427, 2017.

163. Li H, Zhang P, Luo J, Hu D, Huang Y, Zhang ZR, Fu Y and Gong T: Chondroitin sulfate-linked prodrug nanoparticles target the Golgi apparatus for cancer metastasis treatment. ACS Nano 13: 9386-9396, 2019.

164.Zappa F, Failli M and De Matteis MA: The Golgi complex in disease and therapy. Curr Opin Cell Biol 50: 102-116, 2018.

165. Borck G, Mollà-Herman A, Boddaert N, Encha-Razavi F, Philippe A, Robel L, Desguerre I, Brunelle F, Benmerah A, Munnich A and Colleaux L: Clinical, cellular, and neuropathological consequences of AP1S2 mutations: Further delineation of a recognizable X-linked mental retardation syndrome. Hum Mutat 29: 966-974, 2008.

166. Ammann S, Schulz A, Krägeloh-Mann I, Dieckmann NM, Niethammer K, Fuchs S, Eckl KM, Plank R, Werner R, Altmüller J, et al: Mutations in AP3D1 associated with immunodeficiency and seizures define a new type of Hermansky-Pudlak syndrome. Blood 127: 997-1006, 2016.

167. Lu J, Tiao G, Folkerth R, Hecht J, Walsh C and Sheen V: Overlapping expression of ARFGEF 2 and Filamin A in the neuroependymal lining of the lateral ventricles: Insights into the cause of periventricular heterotopia. J Comp Neurol 494 476-484, 2006.

168. Vogt G, El Choubassi N, Herczegfalvi Á, Kölbel H, Lekaj A, Schara U, Holtgrewe M, Krause S, Horvath R, Schuelke M, et al: Expanding the clinical and molecular spectrum of ATP6V1A related metabolic cutis laxa. J Inherit Metab Dis, Dec 15, 2020 (Online ahead of print).

169. Pflieger LT, Dansithong W, Paul S, Scoles DR, Figueroa KP, Meera P, Otis TS, Facelli JC and Pulst SM: Gene co-expression network analysis for identifying modules and functionally enriched pathways in SCA2. Hum Mol Genet 26: 3069-3080, 2017.

170. Shestakova A, Zolov S and Lupashin V: COG complex-mediated recycling of Golgi glycosyltransferases is essential for normal protein glycosylation. Traffic 7: 191-204, 2006.
171. Jensson BO, Hansdottir S, Arnadottir GA, Sulem G, Kristjansson RP, Oddsson A, Benonisdottir S, Jonsson H, Helgason A, Saemundsdottir J, et al: COPA syndrome in an Icelandic family caused by a recurrent missense mutation in COPA. BMC Med Genet 18: 129, 2017.

172. Han C, Alkhater R, Froukh T, Minassian AG, Galati M, Liu RH, Fotouhi M, Sommerfeld J, Alfrook AJ, Marshall C, et al: Epileptic encephalopathy caused by mutations in the guanine nucleotide exchange factor DENND5A. Am J Hum Genet 99: 1359-1367, 2016.

173. Dupuis N, Fafouri A, Bayot A, Kumar M, Lecharpentier T, Ball G, Edwards D, Bernard V, Dournaud P, Drunat S, et al: Dymeclin deficiency causes postnatal microcephaly, hypomyelination and reticulum-to-Golgi trafficking defects in mice and humans. Hum Mol Genet 24: 2771-2783, 2015.

174. Utine GE, Taşkıran EZ, Koşukcu C, Karaosmanoğlu B, Güleray N, Doğan ÖA, Kiper PÖ, Boduroğlu K and Alikasifoğlu M: HERC1 mutations in idiopathic intellectual disability. Eur J Med Genet 60: 279-283, 2017.

175. Xing G, Yao J, Wu B, Liu T, Wei Q, Liu C, Lu Y, Chen Z, Zheng $\mathrm{H}$, Yang $\mathrm{X}$ and Cao $\mathrm{X}$ : Identification of OSBPL2 as a novel candidate gene for progressive nonsyndromic hearing loss by whole-exome sequencing. Genet Med 17: 210-218, 2015.

176. Dupuis N, Lebon S, Kumar M, Drunat S, Graul-Neumann LM, Gressens P and El Ghouzzi V: A novel RAB33B mutation in Smith-McCort dysplasia. Hum Mutat 34: 283-286, 2013.

177. Kondo Y, Fu J, Wang H, Hoover C, McDaniel JM, Steet R, Patra D, Song J, Pollard L, Cathey S, et al: Site-1 protease deficiency causes human skeletal dysplasia due to defective inter-organelle protein trafficking. JCI Insight 3: e121596, 2018

178. Carvalho DR, Speck-Martins CE, Brum JM, Ferreira CR and Sobreira NLM: Spondyloepimetaphyseal dysplasia with elevated plasma lysosomal enzymes caused by homozygous variant in MBTPS1. Am J Med Genet A 182: 1796-1800, 2020.

179. Ng BG, Asteggiano CG, Kircher M, Buckingham KJ Raymond K, Nickerson DA, Shendure J, Bamshad MJ; University of Washington Center for Mendelian Genomics, Ensslen M and Freeze $\mathrm{HH}$ : Encephalopathy caused by novel mutations in the CMP-sialic acid transporter, SLC35A1. Am J Med Genet A 173 2906-2911, 2017.

180. Dörre K, Olczak M, Wada Y, Sosicka P, Grüneberg M, Reunert J, Kurlemann G, Fiedler B, Biskup S, Hörtnagel K, et al: A new case of UDP-galactose transporter deficiency (SLC35A2-CDG): Molecular basis, clinical phenotype, and therapeutic approach. J Inherit Metab Dis 38: 931-940, 2015.

181. Wei J, Zhang YY, Luo J, Wang JQ, Zhou YX, Miao HH, Shi XJ, Qu YX, Xu J, Li BL and Song BL: The GARP complex is involved in intracellular cholesterol transport via targeting NPC2 to lysosomes. Cell Rep 19: 2823-2835, 2017.

This work is licensed under a Creative Commons Attribution-NonCommercial 4.0 International (CC BY-NC 4.0) License. 